\title{
Cytogenetic analyses in Paspalum L. reveal new diploid species and accessions
}

\author{
Análises citogenéticas em Paspalum L. revelam novas espécies e acessos diplóides \\ Marisa Toniolo Pozzobon ${ }^{{ }^{*}}$ Ana Caroline de Carvalho Machado ${ }^{\mathrm{II}}$ Magdalena Vaio $^{\mathrm{III}}$ \\ José Francisco Montenegro Valls ${ }^{\mathrm{I}}$ Andréa del Pilar de Souza Peñaloza ${ }^{\mathrm{I}}$ \\ Sileuza dos Santos ${ }^{I}$ Ana Luiza Côrtes ${ }^{\text {IV }}$ Gabriel Hugo Rua $^{V}$
}

\begin{abstract}
Chromosome numbers were counted in 126 new accessions of 50 Paspalum species from Brazil, Argentina, Paraguay and Bolivia. The chromosome numbers 2n=12, 20, 24, 30, 40, 50, 60, 80 were confirmed. Chromosome numbers for $\boldsymbol{P}$. arenarium $(2 n=20), \boldsymbol{P}$. barretoi $(2 n=20)$, P. aff. ceresia $(2 n=40), \boldsymbol{P}$. corcovadense $(2 n=20), \boldsymbol{P}$. crispulum $(2 n=20), \boldsymbol{P}$. flaccidum $(2 n=40)$, P. nummularium $(2 n=20)$, P. scalare $(2 n=20), \boldsymbol{P}$. vescum $(2 n=20)$ and $\boldsymbol{P}$. rectum $(2 n=20)$ and $a$ diploid cytotype of $\boldsymbol{P}$. malacophyllum are reported for the first time. The predominance of tetraploid accessions (43.6\%) was confirmed, but an unusually high number of diploid species (44\%) and accessions (35.7\%) was found. These results open new perspectives for breeding programs, phylogenetic studies, and for research on apomixis control, since diploids of Paspalum are typically sexual.
\end{abstract}

Key words: chromosome, diploid, polyploid, ploidy level, hybrid, genetic resources.

\section{RESUMO}

O número cromossômico foi determinado para 126 novos acessos de 50 espécies de Paspalum do Brasil, Argentina, Paraguai e Bolívia. Foram verificados os números somáticos $2 n=12,20,24,30,40,50,60$ e 80. Estas são as primeiras contagens para $\boldsymbol{P}$. arenarium $(2 n=20), \boldsymbol{P}$. barretoi $(2 n=20), \boldsymbol{P}$ aff. ceresia $(2 n=40), \boldsymbol{P}$ corcovadense $(2 n=20), \boldsymbol{P}$. crispulum $(2 n=20)$, P. flaccidum $(2 n=40)$, P. nummularium $(2 n=20), \boldsymbol{P}$. scalare $(2 n=20), \boldsymbol{P}$. vescum $(2 n=20)$ e $\boldsymbol{P}$. rectum $(2 n=20)$. O nível diplóide $(2 n=20)$ é reportado pela primeira vez para $\boldsymbol{P}$. malacophyllum. Os dados confirmam a predominância de acessos tetraplóides $(43,6 \%)$ no gênero e mostram um número incomumente elevado de espécies (44\%) e acessos diplóides (35,7\%). Estes resultados trazem novas perspectivas para programas de melhoramento, para estudos filogenéticos e para pesquisa orientada ao controle da apomixia, já que em Paspalum as plantas diplóides são tipicamente sexuais.

Palavras-chave: cromossomo, diplóide, poliplóide, híbrido, nível de ploidia, recursos genéticos.

\section{INTRODUCTION}

The genus Paspalum L., with about 350 species (ZULOAGA et al., 2003; DENHAM, 2005), is an important component of South American biodiversity. Its species inhabit areas ecologically diverse throughout North-, Meso-, and South America, with centers of highest diversity in the Brazilian cerrados and the 'campos' of Argentina, Uruguay and Southern Brazil (CHASE, 1929; BARRETO, 1974; NICORA \& RÚGOLO DE AGRASAR, 1987; JUDZIEWICZ, 1990), where several Paspalum species are dominant (VALLS, 1994). Despite its importance and the volume of published data on many different aspects, genetic improvement is only incipient in the genus. Few species have been included into selection programs, and are currently cultivated as forage plants, mostly restricted to the informal taxonomic groups described by CHASE (1929) as Dilatata, Notata and Plicatula. They are $\boldsymbol{P}$. notatum, $\boldsymbol{P}$. dilatatum, $\boldsymbol{P}$. plicatulum and $\boldsymbol{P}$. guenoarum (VALLS, 1992), and most

\footnotetext{
IEmbrapa Recursos Genéticos e Biotecnologia (Cenargen), Parque Estação Biológica (PqEB). Av. W/5 Norte (final), 70770-900 Brasília, DF, Brasil. E-mail: marisa@cenargen.embrapa.br. *Autor para correspondência.

${ }^{\mathrm{II} C u r s o ~ d e ~ C i e ̂ n c i a s ~ B i o l o ́ g i c a s, ~ U n i v e r s i d a d e ~ C a t o ́ l i c a ~ d e ~ B r a s i ́ l i a ~(U C B), ~ D F, ~ B r a s i l . ~}$

IIIDepartamento de Biología Vegetal, Facultad de Agronomía, Universidad de la República, Montevideo, Uruguay.

${ }^{\mathrm{IV}}$ Curso de Ciências Biológicas, Centro Universitário de Brasília (UniCEUB), DF, Brasil.

${ }^{v}$ Cátedra de Botánica Agrícola, Facultad de Agronomía, Universidad de Buenos Aires, Buenos Aires, Argentina.
} 
recently, P. atratum Swallen (KRETSCHMER et al., 1994). Also P. vaginatum was improved to some extent, and is currently cultivated as turfgrass (DUNCAN \& CARROW, 2000).

Poliploidy is frequent in the genus, with predominance of the tetraploid level (QUARÍN, 1992). Cytological studies show that many Paspalum 'species' consist of both sexual, self-incompatible diploid cytotypes, and apomictic, pseudogamous, and self-fertile polyploids (QUARÍN \& NORRMANN, 1990; QUARÍN, 1992; VALLS, 2000). Thus, they can originate agamic complexes, in which the very concept of 'species' becomes doubtful. According to SAVIDAN (1987), the units breeders have to deal with, in the case of agamic complexes, override the notion of botanical species and include more than one species or even several genera. By fixing interspecific forms that would have been eliminated in a sexual regimen, apomixis exceeds the boundaries of species and creates a continuous variability, making the botanical work difficult. On the other hand, breeders depend on a core collection, which must represent the natural variability of the species to be improved. The occurrence of apomixis and a wide range of ploidy levels make the knowledge on cytology and reproductive behavior of all available accessions an imperative issue for Paspalum improvement (NORRMANN et al., 1989). Routinely, crossing programs require knowing at least chromosome numbers and mode of reproduction of the potential parents.

In this paper, we report chromosome numbers for a range of new accessions of Paspalum, collected in West-central and Southern Brazil, Northeastern Argentina, Paraguay and Bolivia. This contribution significantly enlarges the known variability of South American Paspalum species, and contributes to future breeding programs through new available sexual-diploid accessions.

\section{MATERIAL AND METHODS}

All the accessions analysed are part of the germplasm collections of Paspalum maintained at EMBRAPA Genetic Resources and Biotechnology (EMBRAPA CENARGEN), Brasília, DF, Brazil, and/or at 'Lucien Hauman' Botanical Garden, University of Buenos Aires, Argentina, and have voucher specimens deposited at their respective institutional herbaria (CEN and BAA). The collections were made in locations of the West-central and Southern regions of Brazil, Northeastern Argentina, Paraguay and Bolivia (Tables 1 to 4$)$.

Somatic chromosome numbers were determined in root-tip cells, following the protocols of
POZZOBON \& VALLS (1997), with minor modifications. Meiotic chromosomes were analysed in pollen mother cells from anthers fixed in ethanol-acetic acid 3:1 and squashed in $1 \%$ propionic carmine. At least five cells with good chromosome spreading and no overlapping were analysed per plant. Semi-permanent slides were examined using a light microscope and recorded by photomicrography.

\section{RESULTS}

The chromosome numbers for 126 new germplasm accessions of Paspalum, including 50 species, one of them with two varieties, are listed in tables 1 to 4 . For a better understanding and further discussion of these results, the number of chromosomes is represented as $2 \mathrm{n}$ for all plants, even when obtained from meiotic pollen-mother-cells. The species are referred to the informal groups, as proposed by CHASE (1929) and revised by other authors (PARODI \& NICORA, 1966; BARRETO, 1974; ZULOAGA \& MORRONE, 2005). Nevertheless, such grouping has to be reviewed, since preliminary molecular studies (SPERANZA \& RUA, unpubl.) suggest they are not consistent with the phylogeny of the genus. This is pointed out in the discussion, as relevant.

With the exception of Paspalum almum $(2 n=12,24)$, all the species studied here have chromosome numbers which are multiples of 10, varying from diploids to octoploids. The results show a surprisingly high frequency of diploid species (44\%), as well as diploid accessions (35.7\%), when compared to the predominant tetraploids (43.6\%) and the remaining ploidy levels (20.7\% altogether).

Chromosome numbers are reported for the first time for the following species: Paspalum arenarium, $P$. barretoi, $P$. corcovadense, $P$. crispulum, $P$. nummularium, $P$. scalare, $P$. vescum and $P$. rectum 3, with $2 \mathrm{n}=20$ (Table 1, 3 and 4), and P. aff. ceresia and P. flaccidum with $2 \mathrm{n}=40$. Moreover, two accessions of P. malacophyllum (subg. Anachyris) showed $2 \mathrm{n}=20$, and are the first diploid accessions reported for this species. Pentaploid $(2 n=50)$ accessions of $\boldsymbol{P}$. mandiocanum var. subaequiglume are also reported for the first time. All remaining chromosome counts reported here (Table 1, 3 and 4) confirm previous data (see Discussion below). Special mention is made to $\boldsymbol{P}$. conduplicatum, of the Notata group, of which only two previous counts of $2 n=60$ were mentioned in the literature (RODRIGUES et al., 2001; SOUZA-CHIES et al., 2006), and is here confirmed as an hexaploid, with 14 novel counts sampling its whole area of occurrence 
Table 1 - Paspalum species of subgenus Paspalum, informal group Notata and allies (in bold), and accessions analised (identified by collector's abbreviation and number), with respective origin, chromosome number and informal grouping.

\begin{tabular}{|c|c|c|}
\hline Species / Collector's number (Place of collection) & $2 n$ & Informal group \\
\hline P. almum Chase & & Notata, Alma \\
\hline Gh 582 (ARG, Corrientes, Mercedes) & 12 & \\
\hline V 14440 (RS, São Gabriel) & 24 & \\
\hline P. barretoi Canto-Dorow, Valls \& Longhi-Wagner & & Notata \\
\hline $\begin{array}{l}\text { Gh 731, V 14395*, V 14397, V } 14846 \text { (SC, São Joaquim); Gh 736, V } 14853 \text { (SC, Bom Jardim da } \\
\text { Serra) }\end{array}$ & $20 *$ & \\
\hline P. conduplicatum Canto-Dorow, Valls \& Longhi-Wagner & & Notata \\
\hline $\begin{array}{l}\text { V } 8097 \text { (SC, Bom Retiro); V 8180, V } 14854 \text { (SC, São Joaquim); V } 10553 \text { (SC, Irani); V } 11094 \text { (PR, } \\
\text { Balsa Nova); V } 11143 \text { (PR, Quatro Barras); V } 11250 \text { (PR, Castro); V } 11374 \text { (PR, Guarapuava); V } \\
11386 \text { (SC, São Lourenço d’Oeste); V } 11453 \text { (PR, Palmas); V 14271*** (RS, São Gabriel); V } \\
\text { 14816, V } 14817 \text { (PR, Mangueirinha); V } 14838 \text { (PR, Prudentópolis); V } 14859 \text { (RS, Ipê) }\end{array}$ & 60 & \\
\hline P. crispulum Swallen & & Linearia, Notata \\
\hline Gh 631* (GO, Niquelândia) & $20 *$ & \\
\hline P. equitans $\mathrm{Mez}$ & & $\begin{array}{l}\text { Fasciculata, } \\
\text { Notata }\end{array}$ \\
\hline V 14377 (RS, Caseiros) & 20 & \\
\hline$P$. ionanthum Chase & & Notata \\
\hline $\begin{array}{l}\text { V } 14274 \text { (RS, Cachoeira do Sul); V 14288*** (RS, Capão da Canoa); V } 14791 \text { (RS, São Pedro do } \\
\text { Sul); V } 14894 \text { (RS, Sertão de Santana) }\end{array}$ & 40 & \\
\hline V 14343 (RS, Triunfo) & 80 & \\
\hline P. lineare Trin. & & Linearia, Notata \\
\hline Gh 665 (DF, APA da Cafuringa) & 40 & \\
\hline P. maculosum Trin. & & Notata, Maculosa \\
\hline Gh 487 (ARG, Corrientes, Santo Tomé); V 14345*** (RS, Triunfo) & 20 & \\
\hline $\begin{array}{l}\text { V } 14360 \text { (RS, São José do Herval); V } 14375 \text { (RS, Caseiros); V } 14790 \text { (RS, São Pedro do Sul); V } \\
14848 \text { (SC, Bom Jardim da Serra) }\end{array}$ & 40 & \\
\hline P. minus E. Fourn. & & Notata \\
\hline V 14573*** (MS, Ponta Porã) & 50 & \\
\hline P. nummularium Chase ex Send. \& A.G. Burman & & Notata \\
\hline Gh 737, V 14850* (SC, Bom Jardim da Serra) & $20 *$ & \\
\hline P. pumilum Nees & & Notata \\
\hline $\begin{array}{l}\text { V } 14272 \text { (RS, São Gabriel); V } 14280 * * * \text { (RS, Xangri-lá); V } 14325 \text { (RS, Capivari do Sul); V } 14792 \\
\text { (RS, São Pedro do Sul); V } 14847 \text { (SC, São Joaquim); V } 14889 \text { (SC, Florianópolis) }\end{array}$ & 20 & \\
\hline
\end{tabular}

Collectors: V: J.F.M. Valls and collaborators, Gh: G.H. Rua.

Brazilian States: DF Distrito Federal; GO: Goiás; MS: Mato Grosso do Sul; PR: Paraná; RS: Rio Grande do Sul; SC: Santa Catarina. Other countries: ARG: Argentina.

*First chromosome count for the species; *** Chromosome numbers previously mentioned in SOUZA-CHIES et al. (2006) as “unpublished [data] informed by J. F. M. Valls".

(Table 1). In fact, this species had its regular chromosome pairing (30 bivalents) described long ago (FERNANDES, 1971; FERNANDES et al., 1974), under the tentative name $\boldsymbol{P}$. aff. minus (CANTO-DOROW et al., 1995).

\section{DISCUSSION}

Species counted for the first time

All accessions of $\boldsymbol{P}$. barretoi and $\boldsymbol{P}$. nummularium proved to be diploid. These species are placed in the Notata group, and are closely related to $\boldsymbol{P}$. pumilum, another species for which only sexual, autogamous diploids are known (BURSON \&
BENNETT, 1971). Although a great variation in ploidy levels occurs within the Notata group, which ranges from $2 n=20$ to 80 , this it seems, is not the case for the three species mentioned above. It would be interesting to study if they may be included in a monophyletic group. On the other hand, $P$. barretoi has been considered elsewhere (ZULOAGA et al., 2003, 2004) as a synonym of $\boldsymbol{P}$. minus, on the basis of morphological similarity. Nevertheless, with the only exception of a count of $2 n=40$ for a Columbian accession (DAVIDSE \& POHL, 1978), all reported counts for $\boldsymbol{P}$. minus in South- and Mesoamerican materials, including that presented here, were 2n=50 (BONILLA \& QUARÍN, 1997). This fact, together with some morphological, 
Table 2 - Paspalum species of subgenus Paspalum, informal groups Plicatula and allies, and Virgata (in bold), and accessions analised (identified by collector's abbreviation and number), with respective origin, chromosome number and informal grouping.

\begin{tabular}{|c|c|c|}
\hline Species / Collector’s number (Place of collection) & $2 n$ & Informal group \\
\hline P. compressifolium Swallen & & Plicatula \\
\hline Gh 734 (SC, São Joaquim); V14359 (RS, São José do Herval) & 40 & \\
\hline P. glaucescens Hack. & & Plicatula \\
\hline V 14207 (RS, Passo Fundo); V 14287 (RS, Capão da Canoa) & 20 & \\
\hline V 14419 (RS, Correia Pinto, RS) & 40 & \\
\hline P. guenoarum Arechav. & & Plicatula \\
\hline Gh 720 (MG, Presidente Kubitschek) & 40 & \\
\hline P. lepton Schult. & & Plicatula \\
\hline $\begin{array}{l}\text { V } 14281 \text { (RS, Xangri-lá); V } 14305 \text { (RS, Rosário do Sul); V } 14322 \text { (RS, Capivari do Sul); V } \\
14344 \text { (RS, Triunfo); V } 14436 \text { (RS, São Gabriel) }\end{array}$ & 40 & \\
\hline P. limbatum Henrard & & Plicatula \\
\hline Gh 45 (PRY, Amambay) & 40 & \\
\hline Gh 372 (BOL, Santa Cruz, Ñuflo de Chávez) & 20 & \\
\hline P. modestum Mez & & Modesta, Plicatula \\
\hline $\begin{array}{l}\text { Gh } 146 \text { (ARG, Corrientes, Gral. San Martín); V } 14269 \text { (RS, São Gabriel); V } 14320 \text { (RS, } \\
\text { Capivari do Sul) }\end{array}$ & 20 & \\
\hline P. plicatulum Michx. & & Plicatula \\
\hline $\begin{array}{l}\text { V } 14196 \text { (RS, Vila Flores); V 14203, V 14204, V 14206, V } 14373 \text { (RS, Passo Fundo); V } \\
14229 \text { (RS, São Luiz Gonzaga); V } 14315 \text { (RS, Barra do Quarai); V } 14341 \text { (RS, } \\
\text { Montenegro); V } 14346 \text { (RS, Triunfo); V } 14351 \text { (RS, São José do Herval) }\end{array}$ & 40 & \\
\hline P. rhodopedum L.B. Sm. \& Wassh. & & Plicatula \\
\hline Gh 729 (RS, Campestre da Serra); V 14355, V 14356, V 14358 (RS, São José do Herval) & 40 & \\
\hline P. aff. rojasii Hack. & & Plicatula \\
\hline V 14386 (RS, Capão Alto) & 20 & \\
\hline Paspalum sp. indet. 1 & & Plicatula \\
\hline V 14197 - (RS, Passo Fundo) & 40 & \\
\hline Paspalum sp. indet. 2 & & Plicatula \\
\hline Gh 818 (DF, Parque Nacional de Brasília) & 40 & \\
\hline P. commune Lillo & & Virgata \\
\hline Gh 325 (BOL, Santa Cruz, Valle Grande) & 40 & \\
\hline P. conspersum Schrad. & & Virgata \\
\hline Gh 572 (PRY, Cordillera) & 60 & \\
\hline P. regnellii Mez & & Virgata \\
\hline V 14410 (SC, Lages); V 14348 (RS, Bom Retiro do Sul) & 40 & \\
\hline P. rufum Nees ex Steud. & & Virgata \\
\hline V 14262 (RS, Uruguaiana) & 40 & \\
\hline
\end{tabular}

Collectors: V: J.F.M. Valls and collaborators; Gh: G.H. Rua

Brazilian States: DF: Distrito Federal; MG: Minas Gerais; RS: Rio Grande do Sul; SC: Santa Catarina.

Other countries: ARG: Argentina; BOL: Bolívia; PRY: Paraguay

ecological, and biogeographical evidences, suggests that the specific status of $\boldsymbol{P}$. barretoi has to be reassessed.

The limits of the Notata group were recently expanded, through the fusion with the former Linearia group (ZULOAGA et al., 2004). A recent molecular study (SOUZA-CHIES et al., 2006) was coherent with this approach, since the Linearia group was shown to be paraphyletic. An accession of $\boldsymbol{P}$. crispulum with $2 \mathrm{n}=20$, a member of the former Linearia group, represents the first cytological report for the species. It is a quite rare species restricted to areas of serpentine soils (PRASAD, 2005) near Niquelândia, Goiás State, in the Brazilian central plateau (OLIVEIRA \& VALLS, 2002; ZULOAGA et al., 2004).

Chromosome counts for the three species of the Recta group (OLIVEIRA \& VALLS, 2002) are provided for the first time (P. flaccidum, $2 \mathrm{n}=40 ; \boldsymbol{P}$. rectum, $2 \mathrm{n}=20$; $\boldsymbol{P}$. vescum, $2 \mathrm{n}=20$ ). This is a group of doubtful relationships within the genus, possibly related to the Cuban $\boldsymbol{P}$. rocanum Léon (CHASE, 1929). ZULOAGA \& MORRONE (2005) consider P. vescum a 
Table 3 - Paspalum species of subgenus Paspalum, of assorted informal groups (in bold), and accessions analised (identified by collector's abbreviation and number), with respective origin, chromosome number and informal grouping.

\begin{tabular}{|c|c|c|}
\hline Species / Collector’s number (Place of collection) & $2 n$ & Informal group \\
\hline P. acuminatum Raddi & & Dissecta \\
\hline V 14248, V 14256 (RS, Uruguaiana) & 40 & \\
\hline P. arenarium Schrad. & & Caespitosa, Setacea \\
\hline V 14279* (RS, Xangri-lá) & $20^{*}$ & \\
\hline P. conjugatum P. J. Bergius & & Conjugata \\
\hline V 14284 (RS, Xangri-lá) & 40 & \\
\hline P. dilatatum Poir. "Comum" & & Dilatata \\
\hline V 14312 (RS, Barra do Quarai) & 50 & \\
\hline P. distichum L. & & Disticha \\
\hline V 14350 (RS, São José do Herval) & 40 & \\
\hline P. falcatum Nees ex Steud. & & Falcata, Lachnea \\
\hline V 14362 (RS, Passo Fundo); V 14376 (RS, Caseiros) & 20 & \\
\hline P. flaccidum Ness & & Recta \\
\hline Gh 753* (PR, Balsa Nova) & $40^{*}$ & \\
\hline P. indecorum Mez & & Caespitosa \\
\hline $\begin{array}{l}\text { Gh } 490 \text { (ARG, Corrientes, Santo Tomé); V } 14226 \text { (RS, São Luiz } \\
\text { Gonzaga); V } 14236 \text { (RS, Santo Antônio das Missões) }\end{array}$ & 20 & \\
\hline P. juergensii Hack. & & Paniculata \\
\hline $\begin{array}{l}\text { V } 14209 \text { (RS, Passo Fundo); V } 14212 \text { (RS, Carazinho); V } 14223 \\
\text { (RS, São Luiz Gonzaga); V } 14425 \text { (SC, Capão Alto) }\end{array}$ & 20 & \\
\hline P. lividum Trin. ex Schltdl. & & Livida, Denticulata \\
\hline $\begin{array}{l}\text { Gh } 466 \text { (ARG, Corrientes, Paso de los Libres); V } 14254 \text { (RS, } \\
\text { Uruguaiana) }\end{array}$ & 40 & \\
\hline P. maritimum Trin. & & Caespitosa, Paniculata \\
\hline Gh 712 (ES, Guaraparí); Gh 715 (ES, Conceição da Barra) & 40 & \\
\hline P. pauciciliatum (Parodi) Herter & & Dilatata, Livida \\
\hline V 14319 (RS, Capivari do Sul) & 40 & \\
\hline P. paucifolium Swallen & & Eriantha \\
\hline Gh 313 (ARG, Corrientes, Mercedes) & 40 & \\
\hline P. rectum Nees & & Recta \\
\hline Gh 832* (GO, Teresina de Goiás) & $20 *$ & \\
\hline P. scalare Trin. & & Parviflora \\
\hline Gh 622* (GO, Alto Paraíso) & $20^{*}$ & \\
\hline P. vaginatum Sw. & & Disticha \\
\hline V 14340 (RS, Arroio do Sal) & 20 & \\
\hline P. vescum Swallen & & Recta \\
\hline Gh 652* (DF, APA da Cafuringa) & $20^{*}$ & \\
\hline
\end{tabular}

Collectors: V: J.F.M. Valls and collaborators; Gh: G.H. Rua

Brazilian States: DF: Distrito Federal; ES: Espírito Santo; GO: Goiás; PR: Paraná; RS: Rio Grande do Sul; SC: Santa Catarina.

Other countries: ARG: Argentina.

*First chromosome count for the species.

synonym of $\boldsymbol{P}$. flaccidum. We believe the materials we analysed represent two distinctive taxa, although we recognize that parallel occurrence of the diploid and tetraploid levels is common in Paspalum species.

The chromosome number of Brazilian P. aff. ceresia, $2 \mathrm{n}=40$ (subgenus Ceresia (Pers.) Rchb.) is reported for the first time. Available counts for Andean P. ceresia are $2 n=40$ (MORRONE et al., 2006) and $2 n=60$ (HOJSGAARD et al., 2005). Thus, chromosome numbers do not correlate with morphological evidences supporting the segregation of the Brazilian material as a different species (RUA et al., unpubl.).

Paspalum corcovadense, $2 n=20$ (Corcovadensia group) and $\boldsymbol{P}$ scalare, $2 \mathrm{n}=20$ (Parviflora group) were also counted for the first time, as well as $\boldsymbol{P}$. arenarium $(2 n=20)$, a species probably related to the North American P. setaceum Michx. (BANKS, 1964, 1966; ZULOAGA \& MORRONE, 2005), an auto- 
Table 4 - Paspalum species of subgenus Paspalum, informal groups Corcovadensia and Quadrifaria, and of subgenera Ceresia, Anachyris, and Harpostachys (in bold), and accessions analised (identified by collector's abbreviation and number), with respective origin, chromosome number and informal grouping.

\begin{tabular}{|c|c|c|}
\hline $\begin{array}{l}\text { Species } \\
\text { Collector's number (Place of collection) }\end{array}$ & $2 n$ & Informal group/ subgenus \\
\hline P. corcovadense Raddi & & Corcovadensia \\
\hline V 14283* (RS, Xangri-lá), V 14291 (RS, Dom Pedro de Alcântara) & $20 *$ & \\
\hline P. inaequivalve Raddi & & Corcovadensia, Inaequivalvia \\
\hline V 14261 (RS, Uruguaiana) & 60 & \\
\hline P. mandiocanum Trin. var. mandiocanum & & Corcovadensia \\
\hline V 14292 (RS, Dom Pedro de Alcântara) & 50 & \\
\hline P. mandiocanum var. subaequiglume I.L. Barreto & & Corcovadensia \\
\hline Gh 301 (PRY, Amambay); V 14800** (RS, Julio de Castilhos) & 50 & \\
\hline $\begin{array}{l}\text { Gh } 746 \text { (PR Balsa Nova); V } 14222 \text { (RS, São Luiz Gonzaga); V } \\
14427 \text { (RS, Capão Alto) }\end{array}$ & 60 & \\
\hline P. quarinii Morrone \& Zuloaga & & Quadrifaria \\
\hline V 14208 (RS, Passo Fundo) & 40 & \\
\hline V 14220*** (RS, São Miguel das Missões) & 20 & \\
\hline P. aff. ceresia (Kuntze) Chase & & subg. Ceresia \\
\hline Gh 632* (GO, Niquelândia); Gh 642(GO, Alto Paraíso) & $40 *$ & \\
\hline P. malacophyllum Trin. & & subg. Anachyris \\
\hline V $14411^{* *}$, V 14855 (RS, Correia Pinto) & 20 & \\
\hline P. unispicatum (Scribn. \& Merr.) Nash & & subg. Harpostachys \\
\hline Gh 506 (ARG, Corrientes, Capital) & 40 & \\
\hline
\end{tabular}

Collectors: V: J.F.M. Valls and collaborators; Gh: G.H. Rua

Brazilian States: GO: Goiás; PR: Paraná; RS: Rio Grande do Sul; SC: Santa Catarina.

Other countries: ARG: Argentina; BOL: Bolívia; PRY: Paraguay.

*First chromosome count for the species; ** First report of the ploidy level for the taxon; *** Chromosome numbers previously mentioned in SOUZA-CHIES et al. (2006) as "unpublished [data] informed by J. F. M. Valls”.

compatible sexual diploid (BANKS, 1966; SPERANZA, unpubl.). Altogether, our counts reveal an unusual number of diploid species and accessions for the genus.

Species with new choromosome numbers

Two accessions of $\boldsymbol{P}$. malacophyllum showed $2 n=20$, representing the first diploids of this species reported in the literature. This is a highly variable species belonging to the subg. Anachyris (MORRONE et al., 2000). Chromosome numbers of $2 n=40$ and $2 n=60$ were known for the species, the tetraploids being largely the most common (BURTON, 1940; GOULD, 1975; BURSON \& HUSSEY, 1998; POZZOBON et al., 2000; PAGLIARINI et al., 2001).

Paspalum mandiocanum comprises two varieties: $\boldsymbol{P}$. mandiocanum var. mandiocanum and $\boldsymbol{P}$. mandiocanum var. subaequiglume. Previously reported chromosome counts were $2 n=50$ for var. mandiocanum and $2 \mathrm{n}=60$ for var. subaequiglume (HONFI et al., 1990), both confirmed in this paper. Furthermore, two accessions with 2 n=50 are here reported, which morphologically belong to var. subaequiglume. This finding establishes the first pentaploid record for this variety, and suggests that the segregation of var. subaequiglume as a distinct species, as proposed by HONFI et al. (1990), requires further evidence, since correlation between morphology and chromosome number is not as direct as formerly thought.

\section{CONCLUSIONS}

The paper presents several new chromosome counts in South American species of Paspalum, revealing an unusually high number of diploid species and accessions. The identification of new diploid accessions renders new materials for genetic improvement, and increases the knowledge on the diversity of the genus. The finding of new diploid species is important for phylogenetic studies using molecular markers, as well as through crossings, to establish relationships between these taxa and to give further support to taxonomic treatments.

\section{ACKNOWLEDGEMENTS}

The authors acknowledge the Conselho Nacional de Desenvolvimento Científico e Tecnológico (CNPq), for grants and scholarships.

Ciência Rural, v.38, n.5, ago, 2008. 


\section{REFERENCES}

BANKS, D.J. Cytological studies in Paspalum, Group Setacea (Gramineae). SIDA, Dallas, v.1, p.306-312, 1964.

BANKS, D.J. Taxonomy of Paspalum setaceum. SIDA, Dallas, v.2, p.269-284, 1966.

BARRETO, I.L. O gênero Paspalum (Gramineae) no Rio Grande do Sul. 1974. 258f. Tese (Livre Docência) Universidade Federal do Rio Grande do Sul, Porto Alegre.

BONILLA, J.R.; QUARÍN, C.L. Diplosporous and aposporous apomixis in a pentaploid race of Paspalum minus. Plant Science, Limerick, v.127, p.97-104, 1997.

BURSON, B.L.; BENNETT, H.W. Chromosome numbers, microsporogenesis, and mode of reproduction of seven Paspalum species. Crop Science, Madison, v.11, p.292-294, 1971.

BURSON, B.L.; HUSSEY M.A. Cytology of Paspalum malacophyllum and its relationship to $\boldsymbol{P}$. jurgensii and $\boldsymbol{P}$. dilatatum. International Journal of Plant Science, Limerick, v.159, p.153-159, 1998.

BURTON, G.W. A cytological study of some species in the genus Paspalum. Journal of Agricultural Research, Washington, v.60, p.193-198, 1940.

CANTO-DOROW, T.S. et al. Espécies novas de Paspalum L. (Poaceae) do Sul do Brasil. Bradea, Rio de Janeiro, v.6, p.331337, 1995.

CHASE, A. The North American species of Paspalum. Contributions to the United States National Herbarium, Washington, v.28, p.1-310, 1929.

DAVIDSE, G.; POHL, R.W. Chromosome numbers of Tropical American grasses (Gramineae). Annals of the Missouri Botanical Garden, Saint Louis, v.65, p.637-649, 1978.

DENHAM, S.S. Revisión sistemática del subgénero Harpostachys de Paspalum (Poaceae: Panicoideae: Paniceae). Annals of the Missouri Botanical Garden, Saint Louis, v.92, p.463-532, 2005.

DUNCAN, R.R.; CARROW, R.N. Seashore Paspalum: the environmental turfgrass. Chelsea: Ann Arbor, 2000. 304p.

FERNANDES, M.I.B.M. Citogenética e evolução do gênero Paspalum (Gramineae): contribuição ao estudo das espécies naturais do Rio Grande do Sul. 1971. $193 \mathrm{f}$. Tese (Doutorado em Genética) - Curso de Pós-graduação em Genética, Universidade Federal do Rio Grande do Sul.

FERNANDES, M.I.B.M. et al. Cytological and evolutionary relationships in Brazilian forms of Paspalum (Gramineae). Caryologia, Firenze, v.27, p.455-465, 1974.

GOULD, F.W. The grasses of Texas. College Station: Texas A\&M University, 1975. 663p.

HOJSGAARD, D.H. et al. Números cromosómicos de especies sudamericanas de Paspalum L. In: CONGRESO ARGENTINO DE GEnÉtiCA, 34., 2005, Trelew. Basic \& Applied Genetics, v.17, Supplement, p.119, 2005.
HONFI, A.I. et al. Estudios cariológicos en gramíneas sudamericanas. Darwiniana, Buenos Aires, v.30, p.87-94, 1990.

JUDZIEWICZ, E.J. Poaceae (Gramineae). In: GÖRTS-VAN RIJN, A.R.A. (Ed.). Flora of the Guianas. Königstein: Koeltz, 1990. p.1-727.

KRETSCHMER, A.E. et al. Preliminary evaluation of Paspalum atratum Swallen (Atra Paspalum): a high quality, seed-producing perennial forage grass for Florida. Soil \& Crop Science Society of Florida Proceedings, Gainesville, v.53, p.60-63, 1994.

MORRONE, O. et al. Revisión de las especies del género Paspalum (Panicoideae: Paniceae), subgénero Anachyris. Candollea, Geneve, v.55, p.105-135, 2000.

MORRONE, O. et al. Chromosome studies in American Panicoideae (Poaceae). Annals of the Missouri Botanical Garden, Saint Louis, v.93, p.647-657, 2006.

NICORA, E.G.; RÚGOLO DE AGRASAR, Z.E. Los géneros de gramíneas de América Austral. Buenos Aires: Hemisferio Sur, 1987. 611p.

NORRMANN, G.A.et al. Cytogenetics and reproductive behavior of different chromosome races in six Paspalum species. Journal of Heredity, Washington, v.80, p.24-28, 1989.

OLIVEIRA, R.C.; VALLS, J.F.M. Taxonomia de Paspalum L., grupo Linearia (Gramineae - Paniceae) do Brasil. Revista Brasileira de Botânica, São Paulo, v.25, p.371-389, 2002.

PAGLIARINI, M.S. et al. Cytogenetic characterization of Brazilian Paspalum accessions. Hereditas, Lund, v.135, p.2734, 2001.

PARODI, L.R.; NICORA, E.G. Apuntes para una monografía del género Paspalum. Buenos Aires: Library of the “Laboratorios de Botánica Lorenzo R. Parodi”, Facultad de Agronomía, Universidad de Buenos Aires. 1966. 75p. (Unpublished manuscript)

POZZOBON, M.T.; VALLS, J.F.M. Chromosome number in germplasm accessions of Paspalum notatum (Gramineae). Brazilian Journal of Genetics, Ribeirão Preto, v.20, p.2934, 1997.

POZZOBON, M.T. et al. Contagens cromossômicas em espécies brasileiras de Paspalum L. (Gramineae). Acta Botanica Brasilica, São Paulo, v.14, p.151-162, 2000.

PRASAD, M.N.V. Nickelophilous plants and their significance in phytotechnologies. Brazilian Journal of Plant Physiology, Campinas, v.17, p.113-128, 2005.

QUARÍN, C.L. The nature of apomixis and its origin in Panicoid grasses. Apomixis Newsletter, Montpellier, v.5, p.8-15, 1992.

QUARÍN, C.L.; NORRMANN, G.A. Interspecific hybrids between five Paspalum species. Botanical Gazette, Chicago, v.151, p.366-369, 1990.

RODRIGUES, L.G. et al. Contagens cromossômicas em espécies brasileiras de Paspalum (Gramineae). In: SIRGEALC. SIMPÓSIO DE RECURSOS GENÉTICOS PARA A AMÉRICA LATINA E O CARIBE, 3., 2001, Londrina. Anais... Londrina: IAPAR, 2001. p.395-397. 
SAVIDAN, Y.H. A apomixia das gramíneas forrageiras tropicais e subtropicais. In: ENCONTRO INTERNACIONAL SOBRE MELHORAMENTO GENÉTICO DE PASPALUM, 1987, Nova Odessa. Anais... Nova Odessa: Instituto de Zootecnia, 1987. p.31-35.

SOUZA-CHIES, T.T. et al. A preliminary approach to the phylogeny of the genus Paspalum (Poaceae). Genetica, Utrecht, v.126, p.15-32, 2006.

VALLS, J.F.M. Impacto do conhecimento citogenético na taxonomia de Paspalum e Axonopus (Gramineae). In: CAVALCANTI, T.B.; WALTER, B.M.T. (Eds.). Tópicos atuais em Botânica. Brasília: SBB/Embrapa Recursos e Biotecnologia, 2000. p.57-60.

VALLS, J.F.M. O potencial de plantas forrageiras tropicais americanas. In: SIMPÓSIO BRASILEIRO DE FORRAGEIRAS E PASTAGENS, 1994, Campinas. Anais... Campinas: CBNA, 1994. p.11-24.
VALLS, J.F.M. Origem do germoplasma de Paspalum disponível no Brasil para a área tropical. In: PIZARRO, E.A. (Ed.) REUNIÓN SABANAS, 1992, Brasília. Red Internacional de Evaluación de Pastos Tropicales-RIEPT. Cali: CIAT; Brasília, DF: EMBRAPA-CPAC, 1992. p.69-80.

ZULOAGA F.O.; MORRONE O. Revisión de las especies de Paspalum para América del Sur Austral. Saint Louis: Missouri Botanical Garden, 2005. 298p.

ZULOAGA, F.O. et al. Catalogue of new world grasses (Poaceae): III. Subfamilies Panicoideae, Aristidoideae, Arundinoideae, \& Danthonioideae. Contributions to the United States National Herbarium, Washington, v.46, p.1-6620, 2003.

ZULOAGA, F.O. et al. O. Systematics of Paspalum group Notata (Poaceae-Panicoideae-Paniceae). Systematic Botany Monographs, Michigan, v.71, p.1-75, 2004. 